\title{
MEMBANGUN KEMANDIRIAN ANAK USIA 2-4 TAHUN MELALUI TOILET TRAINING (Studi Kasus di KB GRIYA NANDA YOGYAKARTA)
}

\author{
Shofiyatuz Zahroh, S.Sos. \\ Universitas Islam Negeri Sunan Kalijaga Yogyakarta \\ Email: shofi.zara@gmail.com \\ Dr. Suyadi, S.Ag., M.A. \\ Universitas Islam Negeri Sunan Kalijaga Yogyakarta \\ Email: suyadi@uin-suka.ac.id
}

\begin{abstract}
The purpose of this study to (1) determine the success of building children's independence through toilet training in Griya Nanda, (2) analyzing ways of planting independence through toilet training in Griya Nanda. Researchers used a qualitative method with a case study approach. Data collection using interview techniques, observation and documentation study. Simple data analysis is used in this study, that is all data is reduced, verified and then drawn a conclusion. The results of this study indicate that Griya Nanda successfully implemented toilet training to foster early childhood independence. The method used is the habituation and modeling or example given by the teacher to children. Through this method, children in Griya Nanda can be said to be independent, ie $90 \%$ of Griya Nanda students aged 2-4 years have passed toilet training very well. This shows that the method used is very suitable with the condition of early childhood who has the nature of observing and imitating what he has seen.
\end{abstract}

Keywords: Independence, toilet training, habituation and modeling

\begin{abstract}
Abstrak
Tujuan penelitian ini untuk (1) mengetahui keberhasilan membangun kemandirian anak melalui toilet training di Griya Nanda, (2) menganalisis cara-cara penanaman kemandirian melalui toilet training di Griya Nanda. Peneliti meggunakan metode kualitatif dengan pendekatan studi kasus. Pengumpulan data menggunakan teknik wawancara, observasi dan studi dokumentasi. Analisis data sederhana digunakan dalam penelitian ini, yaitu semua data di reduksi, diferivikasi kemudian ditarik sebuah simpulan. Hasil penelitian ini menunjukkan bahwa Griya Nanda berhasil menerapkan toilet training untuk menumbuhkan kemandirian anak usia dini. Metode yang digunakan adalah pembiasaan dan modelling atau keteladanan yang diberikan oleh guru kepada anak. Melalui metode ini, anak-anak di Griya Nanda dapat dikatakan mandiri, yaitu 90\% dari anak didik Griya Nanda usia 2-4 tahun telah lulus toilet training dengan sangat baik. Hal ini menunjukkan bahwa metode yang digunakan sangat cocok dengan kondisi anak usia dini yang memiliki sifat suka mengamati dan meniru dari apa yang telah dilihatnya.
\end{abstract}

Kata kunci: Kemandirian, toilet training, pembiasaan dan modelling 


\section{PENDAHULUAN}

Pendidikan Anak Usia Dini (PAUD) merupakan sebuah lembaga pendidikan yang berfungsi untuk membantu anak dalam melewati setiap perkembangannya. Di negara-negara maju lembaga PAUD setara dengan Sekolah Dasar (SD) karena merupakan bagian integral dari sistem pendidikan nasional, hal ini menunjukkan betapa petingnya pendidikan bagi anak usia dini. Seperti pendapat Rousseau (Suyadi dan Maulidya Ulfah,2016) pada masa usia dini merupakan masa-masa peka, dimana anak akan mengingat dengan mudah segala hal yang terjadi dalam hidupnya. Baik kejadian-kejadian buruk ataupun kejadian-kejadian baik, baik yang ia lihat ataupun yang ia dengar.

Setiap anak memiliki hak untuk tumbuh dan berkembang secara optimal, melewati berbagai tugas perkembangannya dengan baik untuk melanjutkan pada tahap perkembangan berikutnya. Namun, setiap anak memiliki masalah yang berbeda dalam melalui setiap tahap perkembangannya, ada yang berkembang dengan sangat cepat, wajar dan ada juga yang lambat. Hal ini dipengaruhi oleh fakor internal seperti motivasi maupun faktor eksternal seperti lingkungan keluarga, pendidikan, bermain dan masyarakat. Dalam melalui setiap tahap perkembangannya, tentu anak membutuhkan bantuan individu lainnya seperti keluarga, masyarakat, ataupun teman sebaya (Yuliana, Suniyadewi, dan Udayana 2018). Hal ini karena lingkungan sosial memiliki peran yang sangat dominan dalam tumbuh kembang anak, salah satunya dalam pembentukan perilaku anak. Dimana, perilaku yang ditampilkan anak merupakan hasil adopsi dari lingkungannya atau hasil sosialisasi dengan lingkungannya. Sebagaimana yang dikatakan Loree dalam Abin Syamsuddin (2007:105) perilaku merupakan suatu proses yang dilalui oleh manusia dalam berinteraksi dengan lingkungannya, seperti belajar bergaul, belajar bertingkah laku dan lain sebagainya.

Masa kanak-kanak awal biasanya disebut dengan "usia pragang" (pregang age), yaitu usia 2-6 tahun. Pada masa ini anak mulai berinterkasi dengan individu di luar lingkungan keluarga, terutama dengan anak-anak seusianya (Hurlock,1997:261). Anak-anak yang pada masa ini berada di lembaga PAUD akan sangat berbeda perkembangannya dengan anakanak yang tidak berada di lembaga PAUD. Hal ini karena, anak-anak yang berada di lembaga PAUD, IQ dan EQ nya akan berkembang dengan optimal. Melalui tenaga-tenaga rofesional, kurikulum yang dirancang serta relasi dengan teman sebaya. Sehingga, anak-anak yang berada di lembaga PAUD akan memiliki hubungan sosial yang lebih baik dibanding anakanak yang tidak berada di lembaga PAUD. Karena anak-anak yang berada di lembaga PAUD telah dipersiapkan secara lebih baik untuk melakukan partisipasi aktif oleh guru-guru yang terlatih dan menghindari hal-hal yang akan menyebabkan anak mengalami trauma sosial. Sehingga, pengalaman menyenangkan yang dialami anak pada awal perkembangannya (Hurlock,1997:256) akan memberikan dampak positif kepada anak, seperti perkembangan fisik motorik yang baik, memiliki sikap sosial yang baik dan lain sebagainya. Sedangkan anak yang memiliki banyak sekali pengalaman buruk pada masa awal perkembangannya cenderung memberikan dampak negatif terhadap anak.

Menjamurnya lembaga Pendidikan Anak Usia Dini (PAUD) di Indonesia mensyaratkan kompetisi yang sangat ketat. Fakta ini menuntut lembaga PAUD untuk memberikan fasilitas pendidikan yang maksimal dan memiliki resource tenaga pengajar yang berkualitas dan kredibel. Sekaligus mendorong masyarakat untuk selektif dan kritis dalam memilih lembaga PAUD untuk anak. Hal ini karena banyak lembaga PAUD yang hanya mementingkan perkembangan kognitif saja dan mengenaympingkan perkembangan afektif. Padahal keduanya saling memberikan kontribusi dalam kehidupan anak.

Lembaga PAUD yang tidak hanya memfokuskan pada perkembangan kognitif anak, akan banyak dilirik oleh para orang tua untuk menitipkan anak-anak mereka. Terutama para orang tua yang memiliki sedikit waktu bersama anak karena harus bekerja. Hal ini karena para orang tua sadar bahwa lembaga PAUD yang tidak hanya fokus pada kemampuan 
kognitif anak akan mampu menanamkan kemandirian dalam diri anak. Sehingga, menitipkan anak pada lembaga PAUD merupakan sebuah langkah yang sangat tepat yang telah diambil oleh orang tua. Melihat perkembangan moral atau perilaku anak-anak masa kini yang sangat buruk. Seperti yang telah diberitakan di berbagai media cetak ataupun elektronik, banyak sekali pelaku peyimpangan dilakukan oleh anak-anak, misalnya kekerasan, pencurian, pemerkosaan, menjual obat-obatan terlarang dan masih banyak lagi yang lainnya. Hal ini menunjukkan bahwa moralitas generasi bangsa mulai mengalami pergeseran nilai-nilai. Tentu hal ini didasari oleh banyak faktor, baik faktor eksternal maupun faktor internal.

Kurikulum juga menjadi syarat penentu lembaga dalam menerapkan pembelajaran kepada anak usia dini. Kurikulum 2013 yang telah dirancag oleh pemerintah sebagai solusi dalam melahirkan generasi bangsa yang cerdas dan unggul telah banyak diterapkan dalam berbagai jenjang pendidikan, dari PAUD sampai SMA. Dalam kurikulum 2013 tidak hanya mengembangkan ranah kognitif saja, melainkan juga mengembangkan ranah afektif, salah satunya adalah soft skill. Mengembangkan soft skill yang dimiliki oleh anak sangat penting untuk membantu anak hidup di dalam masyarakat. Bagaimana ia berinteraksi dengan individu lainnya, bagaimana ia mengambil keputusan dan bagaimana ia mengatasi suatu persoalan yang sedang dihadapinya.

KB Griya Nanda merupakah salah satu lembaga Pendidikan Anak Usia Dini (PAUD) yang berada di Yogyakarta. Griya Nanda menaungi Kelompok Bermain (KB), Taman Kanak-Kanak (TK), Tempat Penitipan Anak (TPA) dan Bimbingan Belajar (BIMBEL). Dari keseluruhan lini ini diterapkan kurikulum 2013 yang mencakup 6 aspek perkembangan anak, serta menumbuhkan kemandirian anak di segala bidang usia. Tentu, metode penerapan kurikulum berbeda-beda sesuai dengan jenjang usia anak, karena setiap usia berada pada tahap perkembangan tertentu. Salah satu hal yang menonjol dalam KB Griya Nanda adalah mengembangkan soft skill anak melalui kemandirian. Cara menumbuhkan kemandirian anak yang dilakukan oleh para guru di KB Griya Nanda merupakan cara yang sangat sederhana, namun memiliki dampak yang sangat baik bagi anak. Upaya membangun kemandirian anak di KB Griya Nanda dikemas melalui Toilet Training. Melalui Toilet Training inilah anak secara bertahap bisa menumbuhkan kemandirian dalam dirinya.

Kemandirian anak penting untuk diperhatikan, karena kemadirian juga akan mempengaruhi perilaku anak. Anak yang memiliki kemandirian tinggi akan mampu bersikap dewasa daripada anak yang memiliki tingkat kemandirian rendah. Karena dengan kemandirian anak akan mampu berpikir sendiri, dan melakukan sesuatu sendiri untuk kebutuhannya, anak akan berani mengambil keputusan yang menurutnya benar. Karena tidak selamanya orang lain akan selalu ada untuk membantunya. Maka dari itu, kemandirian perlu ditanamkan sejak usia dini oleh orang tua dan tenaga pendidik.

\section{METODE PENELITIAN}

Penulis dalam penelitian ini menggunakan metode kualitatif melalui pendekatan studi kasus, yaitu melihat fenomena yang ada di lapangan. Penelitian ini di lakukan di lembaga KB Griya Nanda Yogyakarta. Teknik pengumpulan data melalui observasi langsung, wawancara dan studi dokumentasi. Sumber data dalam penelitian ini adalah kepala kurikulum KB Griya Nanda, beberapa pendidik di kelas Bulan, Matahari Bersinar dan Matahari Ceria, serta dokumen-dokumen penting seperti RKH, RPP, buku penghubung dan lain sebagainya. Secara umum, metode penelitian kualitatif merupakan metode yang digunakan untuk mengupas permasalah secara mendalam. Sehingga, kehadiran peneliti dalam lokasi penelitian menjadi syarat utama dalam penelitian kualitatif. Peneliti menjadi tokoh sentral dalam penelitian ini, peneliti melakukan analisis situasi dengan cara mengamati dan studi dokumentasi, menentukan informan, dan melakukan wawancara. Data- 
data yang diperoleh kemudian di analisis sesuai dengan apa yang dikatakan oleh Miles dan Huberman (dalam Andi Prastowo,2016), yaitu reduksi data, penyajian data dan kesimpulan.

\section{HASIL DAN PEMBAHASAN}

\section{Pengertian Kemandirian}

Ada banyak sekali ilmuan yang memberikan pengertian terkait kemandirian, namun dalam tulisna ini hanya di bahas beberapa saja. Carl Rogers seorang ahli psikologi (Desmita, 2016) yang juga berkonribusi dalam perkembangan anak usia dini mengatakan bahwa pembahasan kemandirian tidak akan terlepas dari pembahasan diri itu sendiri. Autoomy merupakan konsep yang paling dekat dengan kemandirian

Erikson juga (Desmita,2016:185) mengatakan bahwa kemandirian merupakan suatu usaha yang dilakukan oleh anak untuk terlepas dari kekangan orang tua, guru dan orang dewasa lainnya dalam rangka menemukan eksistensi dirinya. Sehingga, secara keseluruhan kemandirian merupakan suatu kondisi dimana individu mampu menentukan sikapnya sendiri tanpa pengaruh dari penilaian orang lain, mampu mengambil keputusan sendiri yang dianggapnya benar, dan memiliki inisiatif sendiri untuk masalah yang dihadapi, memiliki rasa tanggung jawab yang sangat besar atas perbuatannya dan lain sebagainya

\section{Bentuk-Bentuk Kemandirian}

Terdapat tiga bentuk kemandirian menurut Robert Havighurst (Demista,2016:186), yaitu sebagai berikut:

1. Kemandirian emosi yaitu anak mampu mengontrol emosinya sendiri dalam konisi apapun

2. Kemandirian ekonomi yaitu anak mampu mengatur ekonominya sendiri tanpa bantuan orang lain

3. Kemandirian intelektual yaitu anak mampu mengatasi berbagai masalah yang sedang ia hadapi

4. Kemandirian sosial yaitu anak mampu berinteraksi dengan baik di dalam lingkungannya, tanpa melakukan proses imitasi perilaku. Anak mampu menentukan sikapnya sendiri tanpa terpengaruh penilaian dari orang lain.

\section{Perkembangan Kemandirian}

Kemandirian berkembang secara bertahap sesuai dengan tahap perkembangan yang sedang dilalui oleh anak. Sehingga, kemandirian anak perlu dikembangkan sejak usia dini, dan setelah mereka dewasa kemandiriannya sudah sangat kompleks, bagaimana anak mengaplikasikannya dalam kehidupan sehari-harinya. Kemandirian anak usia dini menurut Diane Trister Dogde (Komala,2015:32) dapat dilihat melalui pembiasaan dan kemampuan anak dalam hal mengendalikan emosi, cara bersosialisasi, kepercayaan diri, rasa tanggung jawab terhadap setiap perbuatannya, serta kemampuan fisiknya.

Secara garis besar, kemandirian anak dapat diperoleh melalui pembiasaan diri dan keteladanan atau modelling (Muthahhirah,2017). Pertama anak belum mengerti apa maksud dari suatu tindakan yang diajarkan oleh guru atau orang tuanya, mereka hanya mengikutinya saja, lama-kelamaan mereka akan mencari tahu sehingga mereka paham apa maksud dari tindakan tersebut. Ini menunjukkan bahwa kemandirian itu bisa ditumbuhkan melalui pembiasaan serta terjadi secara bertahap. Selain itu, kemandirian juga bisa dilakukan melalui modelling baik oleh orang tua maupun guru, memberikan contoh yang baik kepada anak yang bisa mendorong kemandirian anak. Misalnya, anak mendoakan temannya yang lagi sakit dengan mengucapkan "Syafakillah", walaupun orang tua ataupun pendidik tidak pernah mengajarkan hal demikian kepada anak, namun anak mendengar dan melihat orang dewasa mengucapkan hal demikian kepada orang yang sedang sakit. Ini menunjukkan 
bahwa anak sangat suka meniru perilaku orang dewasa, sehingga orang dewasa yang berada di sekitar anak memiliki tanggung jawab besar untuk memberikan contoh yang baik kepada anak.

\section{Faktor-Faktor yang Mempengaruhi Kemandirian Anak}

Secara umum, salah satu tujuan diterapkannya kemandirian pada anak usia dini adalah agar anak mampu menolong dirinya sendiri, karena tidak selamanya orang tua atau guru akan selalu ada untuk membantunya. Minimal mereka mampu mengerjakan tugas kesehariannya sendiri (james dalam Sunarty 2016), anak bertanggung jawab atas apa yang telah dibuatnya, serta tidak mudah tersulut emosinya (Darajat,1976), memberdayakan kemampuan diri sendiri sehingga tidak selalu bergantung kepada orang lain, serta memotivasi dirinya sendiri, artinya menghargai apa yang telah ia lakukan. (Suharnan dalam Hidayati 2014). Untuk mengetahui apakah anak tersebut telah mandiri atau tidak, bisa melihat pada ciri-ciri di atas. Tidak semua anak yang berada dalam tahap perkembangan yang sama memiliki tingkat kemandirian yang sama, hal ini tentu dipengaruhi oleh faktor internal dan faktor eksternal.

Solahudin (Salina, Thamrin, dan Sutarmanto 2014) mengatakan bahwa faktor internal meliputi emosi, bagaimana perkembangan emosi anak apakah mereka mampu mengendalikan emosinya dalam setiap situasi yang dihadapinya, dan kemampuan intelektual anak. Sedangkan menurut Ali dan Asrori (2006) faktor internal yang dapat mempengaruhi kemandirian anak meliputi kondisi fisik, jenis kelamin, keturunan, dan urutan kelahiran anak dalam keluarga.

Sedangkan faktor eksternal menurut Solahudin (Salina, Thamrin, dan Sutarmanto 2014) meliputi lingkungan keluarga yang meliputi status ekonomi keluarga, stimulasi, dan pola asuh orang tua. Lingkungan sekolah meliputi pembelajaran di sekolah, cinta dan kasih sayang yang diberikan keluarga maupun guru, kualitas informasi anak dengan orang tua dan status pekerjaan ibu. Lingkungan masyarakat meliputi budaya dan norma-norma yang berlaku serta anggapan masyarakat terhadap anak.

\section{Toilet Training}

Toilet training merupakan upaya yang dilakukan oleh orang tua atau pendidik (Komariah, Mulyanto, dan Nurapriani 2019) agar anak mampu mengontrol buang air besar (bowel control) dan buang air kecil (bladder control). Selain itu, toilet training merupakan salah satu upaya membangun kemandirian anak usia tooddler (2-3 tahun). Sehingga guru maupun orang tua harus menerapkan toilet training dengan tepat kepada anak (Meysialla dan Alini 2018). Disamping untuk menumbuhkan kemandirian toilet training juga memberikan pemahaman kepada anak pentingnya menjaga kebersihan dan kesehatan diri.

Orang tua khususnya ibu memiliki peran vital dalam menerapkan toilet training kepada anak, disamping para pendidik. Sehingga, baik di rumah ataupun di sekolah anak harus mendapatkan pengetahuan toilet training yang tepat agar proses pembentukan kemandirian berlangsung optimal. Artinya, pendidikan yang diterapkan di rumah dan di sekolah harus selaras antara satu sama lain.

Setiap anak berkembang secara individual, artinya walaupun berada dalam tahap perkembangan yang sama belum tentu setiap anak mengalami keberhasilan yang sama dalam melakukan toilet training. Anak yang mengalami keberhasilan dalam hal toilet training (Hidayat dalam Dian Surya Gumilang,2014) tentu ia telah memiliki kesiapan fisik yang cukup, psikologis yang matang serta intelektual yang cukup. Untuk mengetahui keberhasilan anak dalam hal toilet training bisa dilihat melalui ciri-cirinya (Sudilarsih dalam Dian Surya Gumilang,2014), seperti memberitahu orang dewasa di sekitarnya ketika ingin BAK ataupun $\mathrm{BAB}$, memegang jenis kelaminnya dengan ekspresi wajah tertentu seperti menahan $\mathrm{BAB}$ 
atau BAK, tidak mengompol saat tidur, mampu melepas dan menggunakan celana sendiri, memiliki ketertarikan untuk pergi ke kamar mandi dan lain sebagainya.

Sedangkan ketidakmampuan anak dalam melakukan toilet training dapat menimbulkan beberapa masalah (Hooman dalam Dian Surya Gumilang,2014) sosial dan medis, seperti anak akan mengompol dimana saja tanpa memberitahu terlebih dahulu kepada orang dewasa yang ada di sekitarnya, sambelit, infeksi saluran kemih dan lain sebagainya. Maka dari itulah, sangat penting bagi orang tua ataupun pendidik membiasakan toilet training kepada anak.

\section{Upaya Pembiasaan Toilet Training}

Segala proses pembentukan baik sikap, perilaku dan lain sebagainya sangat baik apabila dibiasakan sejak anak masih usia dini. Karena usia dini merupakan peletakan dasar dari segala bidang kehidupan. Begitu juga dengan pembiasaan toilet training dimulai sejak usia dini. Salah satu upaya yang bisa dilakukan agar anak usia dini berhasil dalam toilet training adalah melalui pembiasaan dan modelling (Wina Sanjaya,2007). Melalui dua cara ini lah kemudian orang tua maupun pendidik mampu menumbuhkan kemandirian anak sejak usia dini.

1. Pembiasaan kayaknya

Orang tua ataupun pendidik merupakan individu yang sangat memberikan warna dalam kehidupan anak, terutama kehidupan pendidikannya. Sehingga orang tua ataupun pendidik bertanggung jawab memberikan pembiasaan yang baik dalam membentuk pola perilaku anak. Salah satunya adalah pembentukan kemandirian melalui toilet training. Anak yang belum mengetahui toilet training, perlu dibiasakan untuk melakukan toileting. Misalnya, setiap bangun tidur anak dibiasakan diajak ke kamarmandi untuk BAK ataupun $\mathrm{BAB}$, setellah beberapa menit selesai makan dan minum anak dibiasakan ke kamar mandi, mengajarkan anak untuk membuka dan memasang celananya sendiri dan lain sebagainya. Dengan demikian, anak akan mengulangi kebiasaan tersebut setiap harinya, dan secara tidak sadar anak telah mulai menumbuhkan kemandiriannya.

2. Modelling

Cara yang kedua ini juga sangat efektif agar anak mampu berhasil dalam melakukan toilet training. Hal ini karena sejalan dengan sifat yang dimiliki anak, dimana anak sangat senang mengamati dan meniru perilaku-perilaku yang ia lihat terlepas dari perilaku buruk ataupun baik. Karena anak belum bisa membedakan baik buruknya suatu perialku yang ia adaptasi. Maka dari itulah, orang tua ataupun pendidik berkewajiban memberikan contoh atau modelling yang baik kepada anak.

\section{Jenis-Jenis Peniruan (Modelling)}

Anak memiliki tingkat keingintahuan yang sangat besar dibanding orang dewasa, sehingga anak sangat senang meniru perilaku-perilaku seseorang yang dilihatnya, seperti yang dikatakan Laila (2015:19-21) ada beberapa jenis peniruan perilaku yang dilakukan oleh anak, diantaranya:

a. Peniruan langsung. Anak dapat meniru secara langsung perilaku-perilaku yang dicontohkan oleh model, tentu setelah melalui proses perhatian.

b. Peniruan tidak langsung. Merupakan jenis peniruan yang terjadi secara tidak langsung kepada anak, mislanya anak berimaginasi perilaku karakter yang ada di dalam buku cerita, atau anak mengamati guru yang sedang memberikan contoh kepada temannya.

c. Peniruan sesaat atau seketika. Merupakan jenis perilaku yang hanya ditampilkan saat situasi tertentu saja.

d. Peniruan berkelanjutan. Merupakan perilaku-perilaku umum yang bisa dilakukan dimana saja dan kapan saja.

\section{Langkah-Langkah Peniruan}


Seperti halnya jenis-jenis peniruan, Laila (2015:21-36) juga memaparkan beberapa tahapan atau langkah-langkah peniruan perilaku:

a. Tahap perhatian. Anak harus memberikan perhatian secara penuh kepada modelling agar mampu meniru perilaku yang dicontohkan oleh modeling.

b. Tahap penyimpanan dalam ingatan. Anak memiliki daya ingat lebih tinggi dibanding orang dewasa. Sehingga setiap perilaku yang dicontohkan oleh modelling akan disproses dan disimpan dalam memori anak.

c. Tahap reproduksi. Setelah anak melakukan tahap pertama dan kedua, pada tahap ini tugas anak adalah mengaplikasikan perilaku-perilaku yang telah ia adaptasi dari model.

d. Tahap motivasi. Setelah anak mampu mengaplikasikan perilaku-perilaku yang telah ia adapatasi dari model, maka orang tua ataupun pendidik harus hadir untuk memberikan motivasi kepada anak. Motivasi ini bisa berupa pujian, agar anak senang dan anak akan mengulangi perilaku tersebu kembali pada situasi yang sama. Pada gilirannya, anak akan memiliki pemahaman sendiri bahwa perilaku yang telah ia adopsi merupakan perilaku yang memiliki nilai positif menurut orang dewasa.

\section{Toilet Training dalam KB Griya Nandal}

Toilet training merupakan salah satu usaha untuk melatih anak dalam hal mengontrol buang air kecil dan buang air besar (Effendi,2013). Sehingga, anak yang sudah bisa mengontrol buang air kecil dan buang air besar bisa dikatakan mandiri. Maka dari itulah, salah satu upaya mengembangkan kemandirian anak melalui toilet training seperti halnya yang dilakukan oleh PAUD Griya Nanda.

Sejak di tetapkannya kurikulum 2013 oleh pemerintah, PAUD Griya Nanda sudah mengembangkan kurikulum 2013 dalam proses belajar mengajar anak dari usia 0-4 tahun. Hal ini tentu disesuaikan dengan masing-masing tahapan yang di lalui oleh anak. Ada empat kelompok yang ada di PAUD Griya Nanda sesuai dengan usia anak.

\section{Tabel.1.}

Persebaran Usia di Kelas KB Griya Nanda

\begin{tabular}{|c|c|c|}
\hline Jenis Kelas & Usia & Jumlah \\
\hline Kelas Bayi & 0 tahun & 13 anak \\
\hline Kelas Bintang & 1 tahun & 14 anak \\
\hline Kelas Bulan & 2 tahun & 15 anak \\
\hline Kelas Matahari Bersinar & $2-3$ tahun & 18 anak \\
\hline Kelas Matahari Ceria & $3-4$ tahun & 16 anak \\
\hline
\end{tabular}

Sumber data: data primer

Kelas bayi usia 0 tahun berjumlah 13 anak, kelas bintang usia 1 tahun berjumlah 14 anak, kelas bulan usia 2 tahun berjumlah 15 anak, kelas matahari bersinar usia 2-3 tahun berjumlah 18 anak dan kelas matahari ceria usia 3-4 tahun berjumlah 16 anak. Pada masingmasing kelompok ini memiliki treatmen yang berbeda-beda, baik dalam hal penyampaian materi pokok maupun pembentukan sikap dan pembentukan kemandirian, akan tetapi tujuan dari masing-masing treatmen adalah sama, yaitu mencakup 6 aspek perkembangan.

\section{Pentingnya Kemandirian bagi Anak Usia Dini}

Membangun kemandirian sejak anak usia dini merupakan hal yang sangat penting, bahkan bisa dikatakan urgen melihat situasi dan kondisi yang terjadi saat ini. Dimana, permasalahan yang terjadi saat ini sangat menunjukkan kompleksitasnya. Kompleksitas kondisi sosial saat ini sangat mempengaruhi pertumbuhan anak, bisa dilihat melalui 
fenomena-fenomena sosial yang terjadi belakangan ini, seperti penggunaan alkohol dan obat-obatan, tawuran bahkan hal-hal yang berbau kriminalitas.

Beberapa fakta menunjukkan pentingnya membangun kemandirian sejak usia dini. Pertama, Komaruddin dalam (Sunarty 2016) menunjukkan hasil penelitian bahwa anak yang tidak mandiri menunjukkan bberapa sifat negatif seperti sering terlambat datang ke sekolah karena anak tidak memiliki kesadaran dan rasa tanggung jawab, tidak mengikuti pelajaran yang tidak disukainya, dan lain sebagainya. Kedua, hasil penelitian yang dilakukan oleh Marjohan dalam (Sunarty 2016) menunjukkan bahwa anak yang tidak mandiri akan sering berkeliaran di luar kelas pada jam pembelajaran berlangsung, tidak memiliki semangat yang tinggi dalam belajar, datang ke sekolah hanya untuk bermain, pergi sekolah hanya lah gayagayaan, dan lain sebagainya.

Melihat fakta di atas, sekolah memiliki peran vital dalam menumbuhkan kemandirian anak disamping orang tuanya. Anak yang berada di lembaga Pendidikan Anak Usia Dini (PAUD) sejak usia kurang lebih 2 tahun akan lebih cepat memiliki atau membentuk kemandiriannya dibanding anak yang lingkungan sosialnya hanya di dalam rumah. Hal ini karena, selain anak di didik bersama tenaga ahli, anak juga berkumpul bersama teman-teman sebayanya yang berbeda usia, jenis kelamin, ras, suku bahkan agama. Sehingga, anak lebih cepat memahami kondisi lingungan serta lebih cepat bisa mengontrol emosinya.

Maka dari itulah, PAUD Griya Nanda tidak hanya mengembangkan kecerdasan kognitif saja, melainkan juga kemandirian anak. menurut Bunda Rahayu yang merupakan ketua bidang kurikulum mengatakan bahwa kemandirian anak sangat penting di bentuk pada usia dini, karena anak yang mandiri akan lebih cerdas dalam hal apapun dibanding anak yang tidak mandiri. Hal ini juga sesuai dengan visi misi dari PAUD Griya Nanda itu sendiri, dimana anak setelah lulus dari PAUD Griya Nanda menjadi pribadi yang mandiri. Sehinga kecerdasan sosio-emosionalnya bisa lebih berkembang. Sedangkan untuk kecerdasan intelektual anak bisa bertahap sesuai dengan perkembangan usianya. Karena anak yang sudah mandiri akan lebih percaya diri, mempunyai skill untuk menghadapi problemproblemnya sebagai anak-anak tentunya. Misalnya, bagaimana mereka mengungkapkan ketika kebelet pipis atau BAB.

PAUD Griya Nanda merupakan salah satu lembaga yang mengembangkan toilet training, dimana toilet training yang dikembangkan merupakan salah satu metode untuk menumbuhkan kemandirian anak usia dini, sejak usia 0-4 tahun. Namun, para guru yang biasa dipanggil "bunda" tetap mendampingi anak, mana anak yang harus dibantu, mana anak yang harus diberikan contoh dan lain sebagainya. PAUD Griya Nanda dalam menerapkan toilet training dilengkapi dengan fasilitas yang cukup memadai, yaitu dengan adanya kamar mandi yang dipisah antara anak laki-laki dan anak perempuan. Hal ini untuk menambah pemahaman kepada anak untuk mengenali fungsi-fungsi alat seksualnya, perbedaan antara laki-laki dan perempuan, pentingnya menjaga kebersihan dan kesehatan organ intim tentu disesuaikan dengan usia anak dan tahap perkembangannya. Selain itu memberikan pengetahuan ataupun pemahaman kepada anak terkait pergaulan yang sehat serta resikoresiko yang akan ditimbulkannya (Solihin,2015). Kemudian, menekankan bahwa anak lakilaki ataupun perempuan tidak boleh mendatangi toilet lawan jenisnya.

Metode toilet training dalam upaya membangun kemandirian anak di PAUD Griya Nanda dimasukkan ke dalam RKH (rencana kegiatan harian). Pada jam 9 setelah senam dan makan snack anak-anak dibiasakan untuk membuang air besar ataupun membuang air kecil hal ini karena proses metabolisme tubuh. Metode tersebut diyakini efektif dalam membentuk kemandirian anak didik di PAUD Griya Nanda. Selain itu, anak-anak juga diberikan apresiasi terhadap capaian keberhasilannya dalam membentuk kemandirian anak. Seperti, anak-anak yang sudah mengalami kemajuan diberikan pujian, jempol dan lain sebagainya. Dengan demikian anak-anak merasa senang dan merasa bahwa apa yang dilakukannya itu 
adalah hal yang baik dan benar, sehingga anak-anak akan mengulanginya atau bahkan semakin memperbaikinya untuk mendapatkan reward kembali. Berikut adalah salah satu contoh RKH PAUD Griya Nanda

Tebel.2.

Rencana Kegiatan Harian (RKH) Griya Nanda Kelas Matahari Tema Aku

\begin{tabular}{|c|c|c|c|c|}
\hline Waktu & $\begin{array}{l}\text { Kompetensi dasar- } \\
\text { materi }\end{array}$ & Uraian kegiatan & APE & $\begin{array}{r}\text { Metode } \\
\text { penilaian }\end{array}$ \\
\hline $\begin{array}{l}08: 00- \\
09: 30\end{array}$ & $\begin{array}{l}\text { K. seni } \\
\text { K. sosial emosional }\end{array}$ & $\begin{array}{l}\text { Senam, snack pagi, } \\
\text { minum air putih, toilet } \\
\text { training }\end{array}$ & & observasi \\
\hline $\begin{array}{l}\text { 09:30- } \\
10: 30 \\
\text { p. awal }\end{array}$ & $\begin{array}{l}\text { K. NAM } \\
\text { KD.4.1 melakukan } \\
\text { kegiatan beribadah } \\
\text { sehari-hari dengan } \\
\text { tuntutan orang dewasa } \\
\text { (doa-doa) } \\
\text { K. bahasa } \\
\text { Kd.3.10 memahami } \\
\text { bahasa reseptif } \\
\text { (menjawab ketika } \\
\text { ditanya) }\end{array}$ & 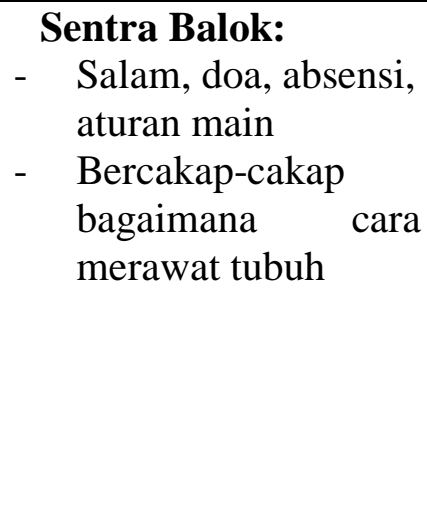 & $\begin{array}{l}\text { Gambar } \\
\text { Lagu } \\
\text { Tepuk } \\
\text { tangan }\end{array}$ & Dialog \\
\hline p. main & $\begin{array}{l}\text { K. kognitif } \\
\text { Kd.3.6 mengenal } \\
\text { benda-benda } \\
\text { disekitarnya (nama, } \\
\text { warna, bentuk dan ciri } \\
\text { lainnya) } \\
\text { K. fisik motorik } \\
\text { Kd.4.3 } \\
\text { mengembangkan } \\
\text { anggota tubuh untuk } \\
\text { mengembangkan } \\
\text { motorik halus } \\
\text { K. seni } \\
\text { Kd.3.15 mengenal } \\
\text { berbagai aktivitas } \\
\text { karya dan seni }\end{array}$ & 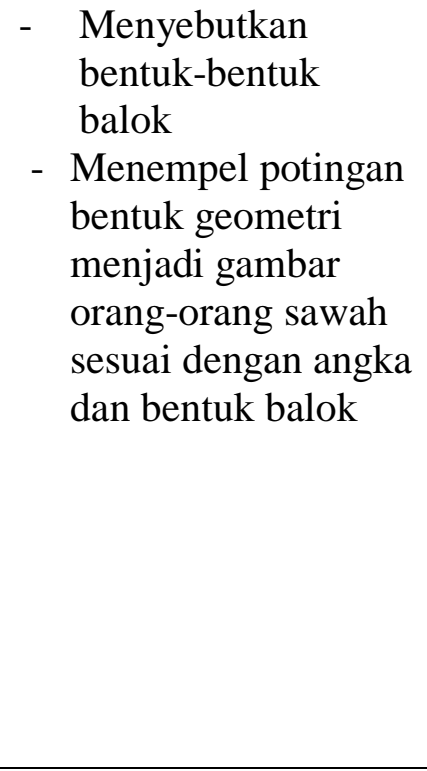 & $\begin{array}{l}\text { Kertas } \\
\text { bentuk } \\
\text { balok, lem }\end{array}$ & $\begin{array}{l}\text { Dialog } \\
\text { Ceklis }\end{array}$ \\
\hline p. akhir & $\begin{array}{l}\text { Review, } \\
\text { mengembalikan alat- } \\
\text { alat yang dipakai, } \\
\text { menanyakan perasaan } \\
\text { saat bermain inti }\end{array}$ & & & \\
\hline $\begin{array}{l}10: 30- \\
11: 00\end{array}$ & Kegiatan ekstra & $\begin{array}{l}\text { Iqro, menyanyi, } \\
\text { menari, cerita }\end{array}$ & $\begin{array}{l}\text { Buku iqro, } \\
\text { VCD }\end{array}$ & \\
\hline
\end{tabular}

Sumber data: data primer

Kemudian, anak-anak yang belum lulus toilet training akan meniru perilaku temannya tersebut yang mendapatkan reward dari bundanya. Seperti yang dikatakan oleh Bandura dalam Laila (2015), bahwa anak-anak lebih senang melakukan imitasi perilaku dari 
sesamanya dibandingkan melakukan imitasi perilaku orang dewasa. Sehingga, 90\% dari peserta didik di PAUD Griya Nanda bisa dikatkan mandiri berdasarkan kemampuan anak dalam hal mengontrol buang air besar dan buang air kecil. Kelompok Bulan, kelompok Matahari Ceria dan kelompok Matahari Bersinar semua anak telah lulus toilet training. Sedangkan kelas Bintang dan Bayi belum lulus toilet training secara sempurna.

Saat melakukan observasi, peneliti melihat secara langsung peserta didik yang sudah terbentuk mental kemandiriannya. Anak didik yang berusia 2 tahun bisa melakukan aktivitas membuka pampersnya sendiri. Ketika pelaksanaan toilet training, anak usia 2 tahun yang telah menerima pembelajaran kemandirian oleh guru Griya Nanda membuktikan telah mampu menangkap pesan pembelajarannya, sekaligus menunjukkan bahwa metode pembelajaran beserta pendekatannya kepada anak-anak didik berada di jalur yang benar atau tepat. metode 'pembiasaan' dan modelling seorang guru kepada anak-anak usia dini memiliki efek pengaruh yang efektif dalam perkembangan perilaku anak usia dini.

\section{Metode Pembelajaran}

Metode pembelajaran di PAUD Griya Nanda menuntut anak lebih aktif daripada guru. Artinya, guru tidak hanya menyampaikan materi akan tetapi harus ada feedback dari anak. Setiap permulaan pembelajaran anak-anak harus mengingat peraturan-peraturan yang telah ditentukan. Semua anak telah berhasil menghapal, mengucapkan bahkan menerapkannya. Misalnya, salah satu peraturannya adalah harus menggunakan tangan dan kaki untuk menolong sesama. Jadi ketika ada satu anak yang memukul temannya, ia akan memberikan respon dengan cara mengingatkan bahwa tangan dan kaki digunakan untuk membantu teman bukan untuk memukul, dan contoh-contoh yang lain. Hal ini juga merupakan perilaku yang dibentuk atas dasar pembiasaan dan modelling dari guru. maka dari itulah, menjadi seorang pendidik anak usia dini haruslah kreatif agar anak tidak bosan berada dalam kelas serta mampu menggali potensi-potensi anak yang masih terpendam. Fakta ini menunjukkan bahwa anak telah mampu menginterpretasi nilai-nilai yang telah diketahuinya pada kehidupan yang sebenarnya. Sehingga, apa yang dikatakan oleh bunda Hayu sebagai kepala kurikulum dapat dibuktikan, bahwa anak yang mandiri lebih cerdas dibanding anak yang hanya dikembangkan kognitifnya saja.

Walaupun demikian, metode toilet training yang diterapkan oleh PAUD Griya Nanda dalam upaya meningkatkan kemandirian anak berhasil. Salah satu kelemahan yang harus segera dievaluasi adalah dokumentasi perkembangan anak yang tertulis. Catatan kemajuan anak dalam hal toilet raining belum ada catatan secara khusus untuk mendokumentasikan perkembangan atau kemajuan anak, sehingga perkembangan anak cepat, efektif, atau lamban, tidak bisa dilihat dalam dokumentasi perkembangan anak. Para guru di PAUD Griya Nanda hanya mengandalkan ingatannya saja, akan tetapi memang betul ketika peneliti melakukan crosscek kepada para guru, para guru hapal siapa saja yang sudah sempurna toilet training-nya, siapa saja yang lulus toilet training, yang hampir lulus dan yang masih dalam tahap proses. Untuk catatan anekdot dan catatan-catatan kemajuan anak yang lainnya memang sudah ada.

\section{Kesimpulan}

Membangun kemandirian anak sejak usia dini sangatlah penting, dimana anak usia dini merupakan pondasi dari seluruh bidang pendidikan. Sehingga, tidak hanya pendidikan kognitif saja yang penting untuk dikembangkan, melainkan ranah afetif juga sangat penting untuk dikembangkan. Hal ini karena dengan mandiri, anak-anak akan menjadi lebih cerdas dan inovatif dalam menyelesaikan setiap masalah dalam kehidupannya. Bisa dikatakan bahwa anak-anak yang pada usia 2-4 tahun telah lulus toilet training berada selangkah lebih maju dibanding anak-anak yang belum lulus toilet training. 
Toilet training sebagai upaya membangun kemandirian anak yang diterapkan oleh PAUD Griya Nanda mencapai keberhasilan yang sempurna, karena 90\% dari anak didik Griya Nanda telah mencapaikemandiriannya, ditandai keberhasilan mereka dalam melakukan toileting. Keberhasilan ini tentu tidak dicapai dengan sangat mudah, pembiasaan toilet training di Griya Nanda dilakukan dengan dua cara, yaitu pembiasaan dan modelling.

\section{DAFTAR PUSTAKA}

Ali, Mohammad dan Mohammad Asrori. 2006. Psikologi Remaja: Perkembangan Peserta Didi, Jakarta: Bumi Aksara

Baron, Robert A. dan Donn Byrne.2003 Psikologi sosial, edisi kesepuuh jilid 1. Jakarta: Erlangga

Darajat Zakiah. 1976. Perawatan Jiwa untuk Anak-Anak, Jakarta: Bulan Bintang

Desmita.2016. Psikologi Perkembangan Peserta Didik. Bandung: Remaja Rosdakarya

Hadiyah, Rifa. 2009. Psikologi Pengasuhan Anak. Malang: UIN Malang Press

Hurlock, Elizabeth B. 1997. Perkembangan Anak, jilid 1, edisi keenam, tt: Gelora Aksara Pratama

Markum, M. Enoch. 2014. Psikologi Sosial. Tangerang Selatan: UniversitasTerbuka

Prastowo, Andi. 2016. Metode Penelitian Kualitatif dalam Perspektif Rancangan Penelitian. Yogyakarta: Ar-Ruzz Media

Sanjaya, Wina. 2007. Strategi Pembelajaran Berorientasi Standar Proses Pendidikan, Jakarta: Prenada media

Sarwono, Sarlito W. Dkk. 2011. Psikologi Sosial. Jakarta: Salemba Humaika

Syamsuddin, Abin. 2007. Psikologi Kependidikan: Perangkat Sistem Pengajaran Modul. Bandung: Remaja Rosdakarya

Suyadi dan Maulidya Ulfah. 2016. Konsep Dasar PAUD. Bandung: Remaja Rosadakarya

Komala. Mengenal dan Mengembangkan Kemandirian Anak Usia Dini Melalui Pola Asuh Orang Tua dan Guru, Jurnal Tunas Siliwangi, Vo. 1 No. 1 Oktober 2015, hlm. 32. http://e-journal.stkipsiliwangi.ac.id/index.php/tunas-siliwangi/article/view/90. diakses pada 03 Oktober 2019, pukul 14:55.

Hidayati, Nur Istiqomah. 2014. "Pola Asuh Otoriter Orang Tua, Kecerdasan Emosi, Dan Kemandirian Anak SD." Persona:Jurnal Psikologi Indonesia 3 (01). https://doi.org/10.30996/persona.v3i01.364.

Komariah, Kokom, Agus Mulyanto, dan Reni Nurapriani. 2019. "Pengaruh Toilet Training terhadap Kemandirian Anak Usia 4-5 Tahun di TKQ Al-Huda Antapani Wetan Tahun Ajaran 2017-2018." EduChild: Majalah Ilmiah Pendidikan 3 (1): 32-47.

Laila, Qumruin Nurul. 2015. "Pemikiran Pendidikan Moral Albert Bandura." MODELING: Jurnal Program Studi PGMI 2 (1): 21-36.

Meysialla, Langen Nidhana, dan Alini Alini. 2018. "Hubungan Pola Asuh Ibu Dengan Kemampuan Toilet Training Pada Anak Usia 12-24 Bulan Di PAUD Buah Hati Kampar Tahun 2018." Jurnal Ners 2 (2). https://journal.universitaspahlawan.ac.id/index.php/ners/article/view/188. 
Muthahhirah, Muthiah. 2017. "Deskripsi Metode Pembelajaran Dalam Penanaman Kemandirian Pada Anak Kelompok A Di TKIT Nurul Islam Gamping Sleman Yogyakarta." Pendidikan Guru PAUD S-1 6 (7): 713-22.

Salina, Eva, M. Thamrin, dan Sutarmanto. 2014. "Faktor-Faktor Penyebab Anak Menjadi Tidak Mandiri Pada Usia 5-6 Tahun Di Raudatul Athfal Babussalam." Jurnal Pendidikan Dan Pembelajaran Khatulistiwa 3 (6). http://jurnal.untan.ac.id/index.php/jpdpb/article/view/5857.

Sunarty, Kustiah. 2016. "Hubungan Pola Asuh Orangtua Dan Kemandirian Anak." Journal of Educational Science and Technology (EST) 2 (3): 152-60.

Yuliana, Kadek Sopa, Ni Wayan Suniyadewi, dan I. Made Udayana. 2018. "Hubungan Pola Asuh Ibu Dengan Keberhasilan Toilet Training Pada Anak Usia Prasekolah Di Posyandu Balita Banjar Intaran Wilayah Kerja UPT KESMAS Tampaksiring II." Bali Medika Jurnal 5 (2): 91-102. 